\title{
STUDIES ON THE EFFECT OF TRANSPLANTING TIME OF DIFFERENT PADDY VARIETIES IN RELATION TO CLIMATE CHANGE
}

\author{
N.V. Kashid*, P.M. Choudhari, S.M. Kadam and T.J. Bhor \\ Agricultural Research Station, Vadgaon Maval, Pune, Maharashtra 412106 \\ *Corresponding Author: kashidnv@gmail.com
}

\begin{abstract}
:
A field experiment was conducted during 2012-2016 at Agricultural Research Station, Vadgaon Maval, Tal. Maval, Dist. Pune for five years to find out interaction on transplanting windows with different paddy varieties in relation to climate change. From the pooled data it was observed that the transplanting of paddy seedlings of variety PhuleSamruddhiin $2^{\text {nd }}$ week of July produced the highest mean number of panicles per plant(20), mean number of grains per panicle (221), mean grain yield $(61.34 \mathrm{q} / \mathrm{ha})$ and straw yield $(70.61 \mathrm{q} / \mathrm{ha})$ with highest mean net monetary returns ( Rs $83487 /$ ha).Hence timely transplanting of paddy ( $2^{\text {nd }}$ week of July) ultimately increases the productivity of paddy. But if monsoon is delayed up to first week of July, then economical grain yield $(48.73 \mathrm{q} / \mathrm{ha})$, straw yield $(56.37 \mathrm{q} / \mathrm{ha})$ and mean net monetary returns (Rs56221/ha) can be obtained by transplanting the seedlings (14-25 days old) of variety Phule Samruddhi up to $4^{\text {th }}$ week of July.
\end{abstract}

Key words: - Transplanted paddy, Transplanting time, Varieties, Yield and Economics.

\section{INTRODUCTION:}

In case of transplanted paddy, the age of the seedlings during the transplanting plays direct role on the productivity. Generally, it is recommended that the varieties of paddy are transplanted at 25 days after sowing. Seedling vigour is an important contributor to subsequent tillering quality and yield of rice ( $\mathrm{Te}$ Krony and Egli, 1991). Although there are many reports of the benefits of transplanting younger seedlings (Horie et al., 2005; Yamamoto et al., 1995), the seedlings transplanted after 30 days old, shows reduction in yield. Under changing climate situation, following long-standing cultural practices in Asia the average age of seedlings used for transplanting is $30-45$ days and they are transplanted into continuously flooded soils, which is one of the important reason of low productivity. Hence, present study was carried out to evaluate the suitable paddy varieties for particular transplanting date under sub mountain zone and ghat zone of Maharashtra.

\section{MATERIALS AND METHODS:}

The experiment was conducted during 2012-2016 at Agricultural Research Station, Vadgaon Maval, Tal. Maval, Dist. Pune for five years. The experiment was laid out in split plot design. One factor astrans planting time of rice seedlingsas $\mathrm{T}_{1}: 4^{\text {th }}$ week of June, $\mathrm{T}_{2}: 2^{\text {nd }}$ week of July, $\mathrm{T}_{3}: 4^{\text {th }}$ week of July and $\mathrm{T}_{4}: 2^{\text {nd }}$ week of August. Second factor consist of varieties released by Mahatma Phule Krishi Vidhyapeeth as $\mathrm{V}_{1}$ : Indrayani, $\mathrm{V}_{2}$ : Phule Samruddhi, $\mathrm{V}_{3}$ : Bhogawati and $V_{4}$ :Phule Radha. Thus, there were total 16 treatment combinations replicated for three times with the individual gross plot size of $3.75 \mathrm{~m} \times 3.75 \mathrm{~m}$. The total plot size was 380 sqm. Integrated Rice Agro Technology (Four-point method) of rice cultivation was used in the experiment. Black gray rice hull ash @ $1.0 \mathrm{Kg}$ per sq.m. was applied to nursery at the time of sowing. Therice straw of $76 \mathrm{~kg} /$ gross plot was 
added at the time first ploughing in the experimental plot. Glyricidea was added as green manure $114 \mathrm{~kg} /$ gross plot in the experimental plot at the time of transplanting. The rice seed lings were transplanted at $15-25 \mathrm{~cm} \times 15-25 \mathrm{~cm}$ distance as per the treatments. Fertilizer dose was applied through Urea DAP briquettes. The experiment was conducted and the data generated for 2012-13, 2013-14, 2014-15 and 2015-16 was analyzed and pooled for five years.

\section{RESULTS AND DISCUSSION:}

From the pooled data presented in table-1 and 2 , it is revealed that the number of panicles per plantmean number of grains per panicle, grain and straw yield (q/ha) and net returns (Rs/ha) of paddy were affected significantly by different treatments.

Effect of time of transplanting: - From the pooled data presented in table-1, showed that the

mean number of panicles per plant (15) and mean number of grains per panicle (174) were significantly maximum in the treatment of $\mathrm{T}_{2}$ i.e. transplanting the paddy seedlings in the $2^{\text {nd }}$ week of July (15) than rest of all the treatments. From the pooled data presented in table-2, it is found that the treatment $\mathrm{T}_{2}$ i.e. transplanting the paddy seedlings in the $2^{\text {nd }}$ week of July produced significantly more mean grain $(48.70$ q/ha) and straw yield (55.82 q/ha) with highest net returns per ha (Rs. 55478/ ha) than rest of all other treatments. The lowest grain (30.81 $\mathrm{q} / \mathrm{ha}$ ) and straw yield (36.14 q/ha) and net returns per ha (Rs. 16854/ ha) were found in the treatment was $\mathrm{T}_{4}$ i.e. the transplanting the paddy seedlings in the $2^{\text {nd }}$ week of August. Similar observations were recorded by Rao et al. (1996) observed that transplanting during 15-25 Julygave the highest paddy yield and a delay in transplanting up to $4^{\text {th }}$ August reduced the yield by $38.9 \%$.
Effect of varieties: - The pooled data presented in table-2, showed that the mean number of panicles per plant (16) and mean number of grains per panicle (177) were significantly maximum in the treatment of $V_{2}$ i.e. transplanting of paddy variety. The lowest mean number of panicles per plant (10) and mean number of grains per panicle (105) were found in the treatment was $V_{4}$ i.e. transplanting of paddy variety Phule Radha. From the pooled data presented in table-2, it is found that the treatment $V_{2}$ i.e. transplanting of paddy variety Phule Samruddhi produced significantly more mean grain (49.59 q/ha) and straw yield (57.11 q/ha) and net returns per ha (Rs. 57839/ ha) than rest of all other treatments. The lowest grain (31.58 q/ha) and straw yield (33.96 q/ha) net returns per ha (Rs. 13356/ ha) were found in the treatment was $V_{4}$ i.e. transplanting of paddy variety Phule Radha. Similar results were reported by Ahmad et al. (2006).

Effect of Interaction: - The pooled data presented in table-1 and 2, showed that the interaction effect of the factors under study was found to be significant. The highest mean number of panicles per plant (20), mean number of grains per panicle (221), mean grain yield (61.34 q/ha) straw yield (70.61 q/ha) and net monetary returns (Rs. 83487/ha) was recorded by the interaction between the treatment of transplanting the paddy variety Phule Samruddhi $\left(\mathrm{V}_{2}\right)$ at in the $2^{\text {nd }}$ week of July. Hence timely transplanting of paddy (2nd week of July) ultimately increases the productivity of paddy. But if monsoon is delayed up to first week of July, then economical grain yield (48.73 q/ha), straw yield (56.37 q/ha) and mean net monetary returns (Rs56221/ha) can be obtained by transplanting the seedlings (14-25 days old) of variety Phule Samruddhi up to $4^{\text {th }}$ week of July. The lowest mean number of panicles per plant (8), mean number of grains per panicle (89), mean grain (24.59 q/ha) and straw yield (30.22 
q/ha) was recorded by the interaction between the treatment of transplanting the paddy variety PhuleRadha $\left(\mathrm{V}_{4}\right)$ at in the $2^{\text {nd }}$ week of August. Similar results were reported by Vange and Obi (2006).

\section{CONCLUSION:}

The transplanting of paddy seedlings of variety PhuleSamruddhiin2 ${ }^{\text {nd }}$ week of July produced the highest mean number of panicles per plant(20), mean number of grains per panicle (221), mean grain yield (61.34 q/ha) and straw yield (70.61 q/ha) with highest mean net monetary returns ( Rs $83487 /$ ha).Hence timely transplanting of paddy ( $2^{\text {nd }}$ week of July) ultimately increases the productivity of paddy. But if monsoon is delayed up to first week of July, then economical grain yield (48.73 q/ha), straw yield (56.37 q/ha) and mean net monetary returns (Rs56221/ha) can be obtained by transplanting the seedlings (1425 days old) of variety Phule Samruddhi up to 4th week of July.

\section{REFERENCES}

Ahmad, M., Ashraf, M.M., Safdar, M.E., Ali, L. and SaleemAkhtar, M.2006. Role of transplanting times on yield and quality of basmati rice.In: Proceedings of

\author{
International Symposium on \\ Sustainable Crop Improvement and \\ Integrated Management. September 14- \\ 16, at Univ. Agri. Faisalabad (Pakistan): \\ 208-215.
}

Horie, T., Shiraiwa, T.,Homma,K., Maeda, Y. and Yoshida,H. (2005).Can yields of lowland rice resume the increases that they showed in the 1980s. Plant Production Science 8:251-272.

Rao, K.S., Moorthy, B.T.S., Dash, A.B. and Lodh, S.B. 1996. Effect of timeof transplanting on grain yield and quality traits of Basmati-type scented rice (Oryza sativa) varieties in Coastal Orissa. Indian J. Agric.Sci. 66: 333-337.

TeKrony, D. M. and Egli, D. B. (1991). Relationship of seed vigor to crop yield: A review. Crop Science31:816-822.

Vange and Obi (2006).

Yamamoto, Y., Ikejiri, A. and Nitta, Y. (1995). Characteristics of rooting and leaf emergence rate, early growth and heading date of rice seedlings with different plant age in leaf number. Japanese Journal of Crop Science64:556-564. 
Table-: 1. Mean number of panicles per plant and mean number of grains per panicle of paddy as affected by interaction of different treatments. (Pooled Mean)

\begin{tabular}{|c|c|c|c|c|c|}
\hline \multirow[b]{2}{*}{ Transplanting Time } & \multicolumn{4}{|c|}{ Varieties } & \multirow{2}{*}{ Mean } \\
\hline & $\mathbf{V}_{1}-$ Indrayani & $\begin{array}{l}\mathbf{V}_{\mathbf{2}}-\text { Phule } \\
\text { Samruddhi }\end{array}$ & $\begin{array}{l}\mathbf{V}_{\mathbf{3}}- \\
\text { Bhogawati }\end{array}$ & $\begin{array}{l}\mathbf{V}_{\mathbf{4}}-\text { Phule } \\
\text { Radha }\end{array}$ & \\
\hline $\mathbf{T}_{\mathbf{1}}-4^{\text {th }}$ week of June & $\begin{array}{c}15 \\
(173)\end{array}$ & $\begin{array}{c}17 \\
(187)\end{array}$ & $\begin{array}{c}12 \\
(143)\end{array}$ & $\begin{array}{c}10 \\
(108)\end{array}$ & $\begin{array}{c}13 \\
(153)\end{array}$ \\
\hline $\mathbf{T}_{\mathbf{2}}-2^{\text {nd }}$ week of July & $\begin{array}{c}17 \\
(192)\end{array}$ & $\begin{array}{c}20 \\
(221)\end{array}$ & $\begin{array}{c}14 \\
(156)\end{array}$ & $\begin{array}{c}11 \\
(125)\end{array}$ & $\begin{array}{c}15 \\
(174)\end{array}$ \\
\hline $\mathbf{T}_{\mathbf{3}}-4^{\text {th }}$ week of July & $\begin{array}{c}14 \\
(152)\end{array}$ & $\begin{array}{c}16 \\
(172)\end{array}$ & $\begin{array}{c}11 \\
(121)\end{array}$ & $\begin{array}{c}9 \\
(96)\end{array}$ & $\begin{array}{c}12 \\
(135)\end{array}$ \\
\hline $\mathbf{T}_{\mathbf{4}} 2^{\text {nd }}$ week of August & $\begin{array}{c}10 \\
(113)\end{array}$ & $\begin{array}{c}12 \\
(127)\end{array}$ & $\begin{array}{c}10 \\
(107)\end{array}$ & $\begin{array}{c}8 \\
(89)\end{array}$ & $\begin{array}{c}10 \\
(109)\end{array}$ \\
\hline Mean & $\begin{array}{c}14 \\
(158)\end{array}$ & $\begin{array}{c}16 \\
(177)\end{array}$ & $\begin{array}{c}12 \\
(132)\end{array}$ & $\begin{array}{c}10 \\
(105)\end{array}$ & \\
\hline
\end{tabular}

* Figures in the parenthesis indicates mean number of grains per panicle

\begin{tabular}{|r|c|c|}
\hline & $\begin{array}{c}\text { Mean number of panicles } \\
\text { per plant }\end{array}$ & $\begin{array}{c}\text { Mean number of } \\
\text { grains per panicle }\end{array}$ \\
\hline S.E. between levels of A & 0.44 & 15.35 \\
\hline C.D. at 5\% & 1.35 & 5.00 \\
\hline S.E. between levels of B & 0.43 & 15.15 \\
\hline C.D. at 5\% & 1.33 & 143 \\
\hline
\end{tabular}


Table-: 2. Mean grain yield (q/ha),straw yield(q/ha) and net returns (Rs/ha )of paddyas affected by interaction of different treatments. (Pooled Mean)

\begin{tabular}{|c|c|c|c|c|c|}
\hline \multirow[b]{2}{*}{ Transplanting Time } & \multicolumn{4}{|c|}{ Varieties } & \multirow[t]{2}{*}{ Mean } \\
\hline & $\mathbf{V}_{\mathbf{1}}-$ Indrayani & $\begin{array}{l}\mathbf{V}_{\mathbf{2}}-\text { Phule } \\
\text { Samruddhi }\end{array}$ & $\mathbf{V}_{\mathbf{3}}-$ Bhogawati & $\begin{array}{l}\mathbf{V}_{\mathbf{4}}-\text { Phule } \\
\text { Radha }\end{array}$ & \\
\hline $\begin{array}{l}\mathbf{T}_{\mathbf{1}}-4^{\text {th }} \text { week of } \\
\text { June }\end{array}$ & $\begin{array}{c}48.26 \\
(55.05) \\
{[54671]}\end{array}$ & $\begin{array}{c}52.17 \\
(59.61) \\
{[63197]}\end{array}$ & $\begin{array}{c}39.78 \\
(45.31) \\
{[36439]}\end{array}$ & $\begin{array}{c}30.71 \\
(34.20) \\
{[15512]}\end{array}$ & $\begin{array}{c}42.73 \\
(48.54) \\
{[42455]}\end{array}$ \\
\hline $\mathbf{T}_{\mathbf{2}}-2^{\text {nd }}$ week of July & $\begin{array}{c}54.23 \\
(62.21) \\
{[67859]}\end{array}$ & $\begin{array}{c}61.34 \\
(70.61) \\
{[83487]}\end{array}$ & $\begin{array}{c}43.93 \\
(50.47) \\
{[45553]}\end{array}$ & $\begin{array}{c}35.29 \\
(40.00) \\
{[25014]}\end{array}$ & $\begin{array}{c}48.70 \\
(57.01) \\
{[55478]}\end{array}$ \\
\hline $\mathbf{T}_{\mathbf{3}}-4^{\text {th }}$ week of July & $\begin{array}{c}43.91 \\
(49.75) \\
{[45387]}\end{array}$ & $\begin{array}{c}48.73 \\
(56.37) \\
{[56221]}\end{array}$ & $\begin{array}{c}34.73 \\
(40.17) \\
{[25631]}\end{array}$ & $\begin{array}{c}27.91 \\
(31.43) \\
{[9730]}\end{array}$ & $\begin{array}{l}38.82 \\
(44.43) \\
{[34242]}\end{array}$ \\
\hline $\begin{array}{l}\mathbf{T}_{\mathbf{4}}-2^{\text {nd }} \text { week of } \\
\text { August }\end{array}$ & $\begin{array}{c}32.03 \\
(37.19) \\
{[19540]}\end{array}$ & $\begin{array}{c}36.14 \\
(41.86) \\
{[28450]}\end{array}$ & $\begin{array}{c}30.49 \\
(35.30) \\
{[16257]}\end{array}$ & $\begin{array}{l}24.59 \\
(30.22) \\
{[3170]}\end{array}$ & $\begin{array}{c}30.81 \\
(36.14) \\
{[16854]}\end{array}$ \\
\hline Mean & $\begin{array}{c}44.61 \\
(51.05) \\
{[46864]}\end{array}$ & $\begin{array}{l}49.59 \\
(57.11) \\
{[57839]}\end{array}$ & $\begin{array}{c}37.23 \\
(42.81) \\
{[30970]}\end{array}$ & $\begin{array}{c}29.63 \\
(33.96) \\
{[13356]}\end{array}$ & \\
\hline
\end{tabular}

* Figures in the( ) indicates the Straw Yield (q/ha) and [ ] indicates net returns Rs/ha.

\begin{tabular}{|r|c|c|c|}
\hline & Grain yield & Straw yield & Net returns \\
\hline S.E. between levels of A & 1.66 & 1.45 & 3423 \\
\hline C.D. at 5\% & 4.59 & 4.99 & 9828 \\
\hline S.E. between levels of B & 1.47 & 1.63 & 9540 \\
\hline C.D. at 5\% & 4.37 & 5.16 & 37257 \\
\hline
\end{tabular}

